\title{
Retraction Note: Abstracts of the 47th Annual Meeting of the EASD, Lisbon 2011. 'Reduced syntaxin-5 in skeletal muscle of patients with type 2 diabetes is linked to increased diacylglycerol, activation of PKCtheta and impaired insulin signalling'
}

\author{
K. Højlund • P. Boström • B. F. Vind • L. Andersson • \\ S. Myhre • M. Ståhlman • H. Beck-Nielsen • \\ J. Borén • S.-O. Olofsson
}

Published online: 12 November 2014

(C) Springer-Verlag Berlin Heidelberg 2014

\section{Retraction of Diabetologia \\ DOI 10.1007/s00125-011-2276-4}

Abstract 59, presented at the 47th Annual Meeting of the EASD in 2011, has been retracted at the request of the Dean of Sahlgrenska Academy at the University of Gothenburg, Professor Larkö. The University has investigated this case and The Committee on Academic Misconduct finds that Pontus

Boström is guilty of misdemeanour with reference to the points (1) conscious fabrication, corruption or suppression of basic material, and (2) conscious preparation and presentation of falsified results, and therefore finds reason to believe that scientific misconduct has occurred. The primary finding reported in the abstract - reduced protein levels of syntaxin-5 in diabetic muscle — could not be reproduced.

The online version of the original article can be found under doi:10.1007/ s00125-011-2276-4.

K. Højlund $(\bowtie) \cdot$ B. F. Vind $\cdot$ H. Beck-Nielsen

Diabetes Research Centre, University of Southern Denmark,

Odense C, Denmark

e-mail:k.hojlund@dadlnet.dk

P. Boström · L. Andersson · S. Myhre · M. Ståhlman · J. Borén •

S.-O. Olofsson

Wallenberg Laboratory, Göteborg University, Göteborg, Sweden 